ECONOMICS

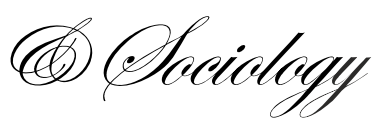

\title{
IMPACT OF SMEs ON STANDARDS OF LIVING OF CZECH RURAL HOUSEHOLDS
}

\author{
Nad'a Birčiaková, \\ Mendel University in Brno, \\ Brno, Czech Republic, \\ E-mail: \\ nada.birciakova@mendelu.cz. \\ Jana Stávková, \\ Mendel University in Brno, \\ Brno, Crech Republic, \\ E-mail:jana.stavkova@mendelu.cz.
}

Received: June, 2015

1st Revision: October, 2015

Accepted: November, 2015

DOI: $10.14254 / 2071-$

789X.2015/8-4/4

\begin{abstract}
This paper deals with an analysis of rural households' perception of their standards of living in context of SME in which they work. The results are based on a primary questionnaire survey conducted by authors among Czech rural households at the end of 2014. Household's subjective opinion on satisfaction with standards of living and SME's contribution to the positive development of its environment are analysed among households divided into groups according to the characteristics of SME in which the head of the household works. The paper points to correlation between SME's legal form and the distance from household's residence and SME's contribution to the development of its environment and also between SME's distance from household's residence and household's satisfaction with standards of living. Findings of the paper help to deeper our knowledge about the connection between SMEs and rural standards of living. They would also help to understand which factors rural development policy should focus on in order to increase interest of population in rural areas or to avoid urbanization. Correlations between variables were analyzed using the method of Pearson's Chi-squared test and Cramer's contingency coefficient using STATA software.
\end{abstract}

Keywords: SME, rural, households, standards of living, Czech Republic.

JEL Classification: I310,
R230

\section{Introduction}

In the last decades, many European countries have to face many negative trends. It applies to many issues, especially rural areas, which are struggling with high unemployment level, high average age, low population density or less accessible services and markets (Terluin, 2003; OECD, 2006). These trends result in deteriorating level of infrastructure, education or business activity, considered as a major factor of rural development (e.g. Bourne, 2011; Mainardes, Alves and Raposo, 2011).

Development of the rural areas is closely connected with small and medium-sized enterprises - SMEs (Holmes and Smitchz, 1990). These companies create new jobs (for example, SMEs employed $61 \%$ of Czech population and $67 \%$ population of European Union - MPO, 2013; EC, 2014) and innovations or increase income level, causing an increase in 
standards of living and prevent population migration into the cities (Walsh et al., 2012; Milbourne and Doheny, 2012; Mottiar and Ryan, 2007).

It is obvious, that SMEs play a crucial role in social, cultural and economic development and without basic rural services (e.g. grocery, post office and restaurant) or sufficient job opportunities, development of standards of living would not be possible.

Although, many authors are focused on the issue of standards of living and SMEs, impact of SMEs on households' standard of living is still unexplored area - especially in terms of the Czech Republic. Therefore, the aim of the authors is to focus on the issue and fill this gap. The main purpose of this article is to determine how households assess the role of SMEs in context of rural development. If they perceive SMEs' activity in the context of standards of living development and if there exist some SMEs' characteristics influence this perception.

\section{Literature review}

It is difficult to think of something else with a greater preoccupation than the standard of living, which is part of people's everyday thoughts. Today's idea of the standard of living is full of contrasts, conflicts and even contradictions. Without general definition, the views on this issue vary and create a disorganized unit (Sen, 1989).

Bennett (1937) already expressed the idea that the standard of living is the most complex and difficult-to-grasp concept. Cottam and Mangus (1942) agree with that and add that some definitions of the standard of living focus more on material consumption.

Vad'urová and Mühlpachr (2005) come with a fundamentally different view, stating that today there is actually a tendency to purely subjective evaluation of quality of life, which indicates a decisive approach.

The category which is intertwined with quality of life is happiness. Many thinkers argue that the existence of the human species is based on happiness and every person should try to get it because it is the most essential goal of human existence (Tefler In Shin and Inoguchi, 2009). Shin and Inoguchi (2009) adds that in professional public it is prevailing a consensus that happiness has a significant impact on quality of life.

The concepts 'standard of living' and 'quality of life' overlap in many areas and their definitions are clearly reserved. Some authors try to include their penetration to the concept of welfare. The thing that the experts agree with is that all these concepts are closely linked to human needs.

Večerník (2012) explains the concept of multidimensional welfare which is a quantifier of standard of living. An important stimulus for the research was Sarkozy's report drawn up by the commission led by Stiglitz, Sen and Fitoussi. According to them, well-being and welfare are influenced by the following external factors-material living standards, consumption and wealth, health, education, personal activities including work, political environment, social contacts and relationships, natural environment, personal and economic uncertainty (Stiglitz et al., 2007).

The most commonly used indicator of the standard of living is gross domestic product per capita. Many economists take GDP growth per capita as the most important goal, but Krugman and Wells (2006) argue that it is not sufficient for measuring human well-being and also it is not a suitable tool for political decisions. When we increase revenue, the output of the economy is growing, but it's up to us whether we use the money to improve the quality of life or not. GDP per capita is not a direct reflection of the standard of living but it is one of many determinants that are involved in it. 
There are interesting studies about the context of wealth and subjective well-being which are summarized in the following paragraphs Diener and Biswas-Diener (In Ryan and Deci, 2001):

- People in the richer countries are happier than those living in poorer countries.

- The increase of national wealth in developed countries has been followed by the growth of subjective well-being, the difference in the Wealth of Nations shows only a weak correlation with happiness.

Growth in personal wealth generally does not lead to the growth of happiness.

Although there is no clear consensus in definitions of standard of living, quality of life, well-being and welfare, the fact is that all these concepts are related to man and their lives. If you want to convert international comparisons, it is necessary to identify the determinants of standard of living. The assumption is that the determinants found out on the base of subjective standard of living will be different in Europe in comparison with Africa, for example. Also, it can be expected that there will be differences between different groups within one country, whether due to economic activity and gender, or a place of residence. Similarly, the sector in which people work constitutes a factor that can cause differences in opinions on the standard of living. For these reasons, the authors of this paper are motivated to focus on a narrow group of people - the rural population of the Czech Republic. There is an interest to find out the interconnection of importance of standard of living factors with SMEs in which the most people in rural regions of the Czech Republic work.

\section{Objective and Methodology}

The aim of the paper is to determine perceived satisfaction of Czech emloyed rural households with standards of living and also to verify ifcharacteristics of small and mediumsized enterprise (its size, legal form and distance from household's residence) have an impact on the satisfaction and also on positive contribution to the development of its environment.

To achieve the aim of the paper, a primary questionnaire survey was conducted among households from rural regions of the Czech Republic at the end of 2014. Czech rural areas were selected based on the New urban-rural typology for the NUTS3 regions - methodology of OECD (OECD, 2015). For the purpose of the paper, the Predominantly rural regions (Plzeňský, Jihočeský, Vysočina, Pardubický, Olomoucký and Zlínský region) and Intermediate regions (Karlovarský, Ústecký, Liberecký, Královehradecký, Jihomoravský and Moravskoslezský region) have been chosen for primary data collection. Households of these areas belonged to the basic statistical set. Based on the random sampling, representative data on economic activity of households (employed, self-employed, retired, unemployed and others - tested by $\chi^{2}$ ) was obtained. The questionnaires were performed by electronic and paper form and representative data from more than 700 households was obtained. 389 questionnaires of these households were usable and used for the purpose of the paper dealing just with 'employed households'. Questionnaires have been excluded because of incompleteness, mistakes or because of the head of household did not work in SME. For example, 121 of them work in micro-sized enterprise, 138 households work in small enterprise and the last 130 households work in medium-sized enterprise. Questionnaires were completed by heads of households who renders infromation esppecially about satisfaction with their standards of living.

In the beginning, 23 factors influencing households' standards of living were defined by authors. Households assesed these factors using the 1-10 scale $(1=$ minimum; $10=$ maximum) based on how important perceive them and also how satisfied are with them in terms of their standards of living. These factors were analyzed in order to identify which of them are (un)important for households and also which of them are households (dis)satisfied 
with. The arithmetic mean was used for the analysis and calculated households' average perceived importance, satisfaction and possible differences between their perception.

In the next step, a correlation between characteristics of SME and SME's impact on the contribution to the development of its environment and household's satisfaction with standards of living were determined. First the null and alternative hypothesis about (in)dependence between observed variables were formulated and tested at significance level of $\alpha=0.05$. The hypotheses testing was performed by using Pearson's Chi-squared test (1) of independence between variables and Cramer's contingency coefficient of strength dependence (2):

$$
\begin{gathered}
\chi^{2}=\sum_{i=1}^{n} \frac{\left(O_{i}-E_{i}\right)^{2}}{E_{i}} \\
V=\sqrt{\frac{\chi^{2} / n}{\min (k-1, r-1)}}
\end{gathered}
$$

where:

$\chi^{2}-$ Pearson's chi-squared test,

$\mathrm{V}-$ Cramer's contingency coefficient,

$\mathrm{O}$ - observed frequencies,

$\mathrm{E}$ - expected frequencies,

$\mathrm{n}$ - number of observations,

$\mathrm{k}$ - number of columns,

$\mathrm{r}-$ number of rows.

In order to scrutinize results in detail, descriptive statistics, such as absolute and relative frequencies, were used to process the obtained data.

The STATA software was used for the analysis.

\section{Results}

Based on results of the primary questinnaire survey, households from predominantly rural regions and intermediate rural regions perceive importance of factors influencing their standards of living almost identical. So there is no factor which would be significantly different in importance for households from these two types of regions.

In the general the most important factors are: 'availability and quality of housing', 'availability and quality of grocery and drugstore' and 'safety' of a village or a town. It is interesting that at the end of the importance are factors like 'availability and quality of services' or 'interpersonal relationships' which many authors identified as important factor influencing households standards of living (e.g. Stiglitz et al., 2007). But there is little variability of perceived importance so differences are not so large. It means that households are not able to differ which factor is more important for their standards of living.

In the case of perceived satisfaction with surveyed factors was found that predominantly rural region households are less satisfied with some factors in comparison of households from intermediate rural regions. The fact concerns in particular these 5 factors of 23: 'availability and quality of education', 'transport connection', 'availability and quality of grocery and drugstore', 'availability and quality of services' and 'availability and quality of sports facilities'. It seems, households are more satisfied with these 5 factors in the intermediate rural regions. Althought there are few differences in satisfaction perception, other 18 factors are perceived nearly identical so we consider these two regions as identical and analyze them together (as in the case of perceived importance). 
In the analysis of order, we found out that households are the most satisfied with 'air quality' and 'safety' in their village or town. On the other hand, they are the most dissatisfied with 'possibility to get a job' and their 'income level' (see Figure 1). And also in the situation when they are employed.

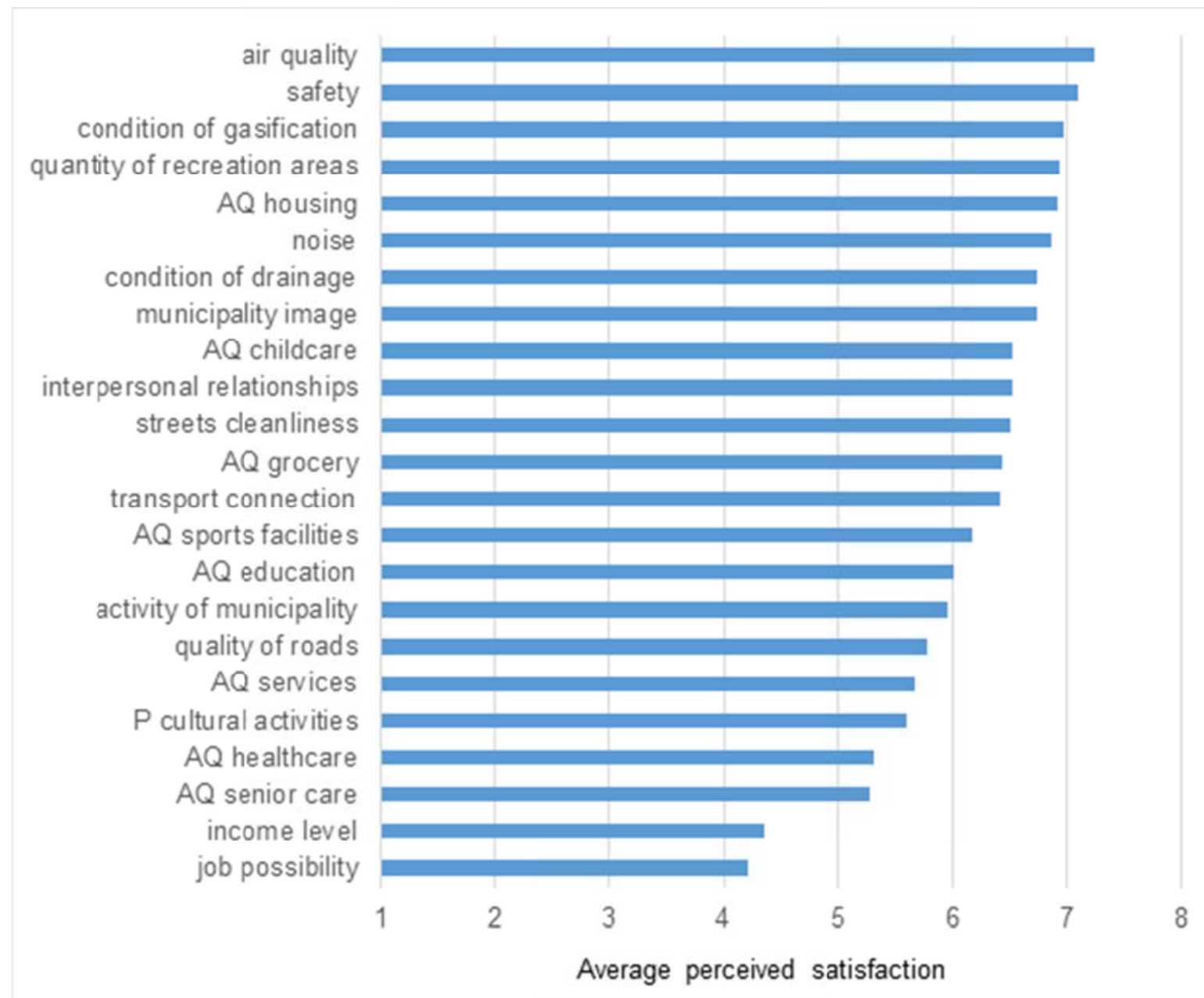

Figure 1. Order of factors influencing standards of living - average perceived satisfaction ${ }^{1}$

The Figure 1 also shows bigger perceive satisfaction variability of factors compared with variability of perceived importance order. So households are able to identify problematic factors of their rural region which they think, should be improved.

Our analysis showed that rural households differently perceive importance and satisfaction. Figure 2 comparises perceived importance and satisfaction with factors influencing standards of living. These factors are sorted by the highest perceived average importance and it is obvious that employed households are not fully satisfied with any surveyed factor.

\footnotetext{
${ }^{1} \mathrm{AQ}=$ availability and quality of; $\mathrm{P}=$ possibility of.
} 


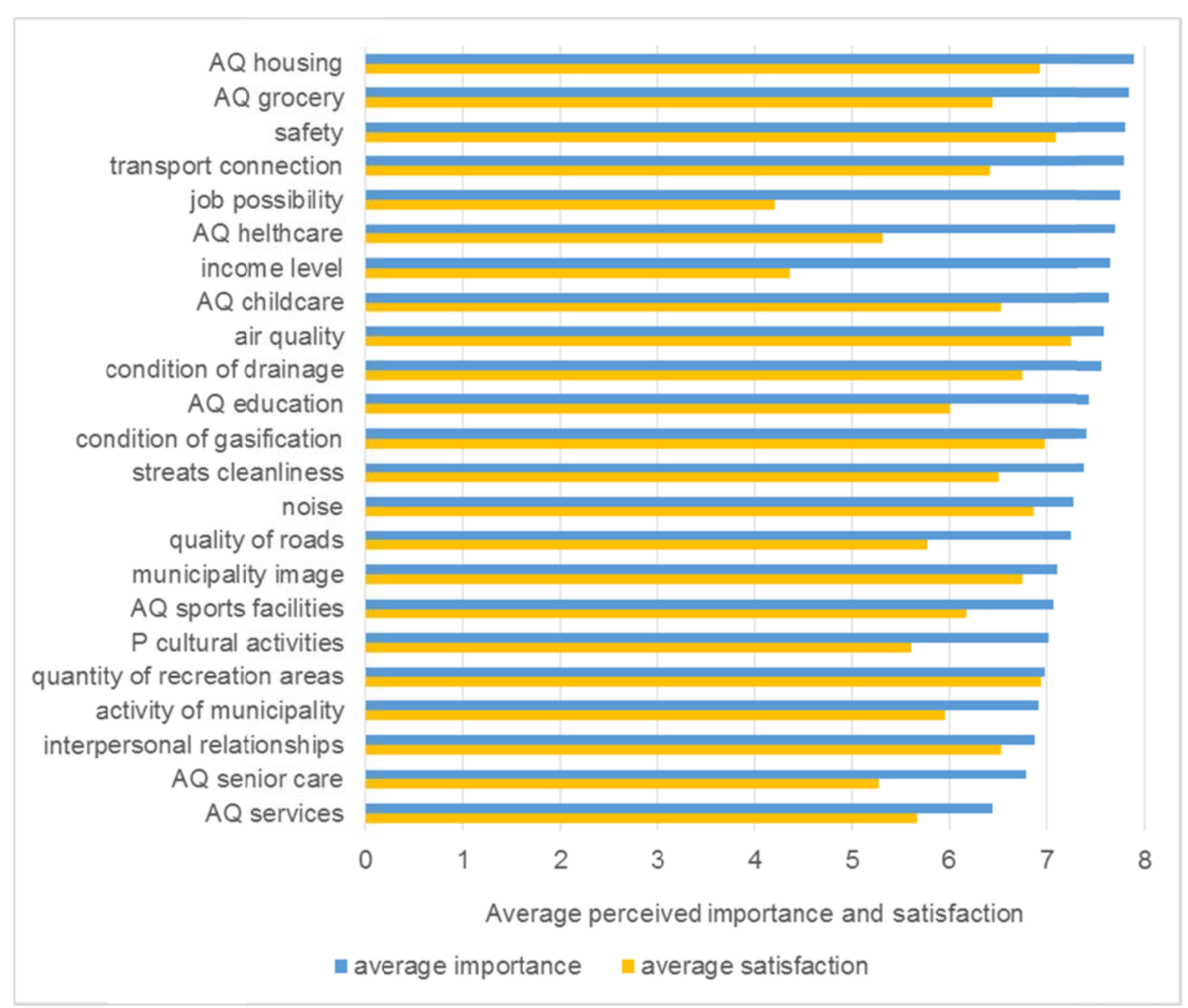

Figure 2. Perceived importance and satisfaction with factors influencing rural standards of living - differences

Precise differences are shown in the Figure 3. Higher column means bigger difference between perceived importance and satisfaction and at the same time bigger difference between expected and actually perceived situation. There are three factors with the bigger differences in the Figure. They are: 'job possibility', 'income level' and 'availability and quality of healthcare'. It means that Czech rural households perceive these three factors problematically and think they should be on a higher level. These results authors have expected. For example, between 22 EU countries, there is the 5th lowest level of minimun wages in the Czech Republic (Eurostat, 2015) or Czech government expenditures on healthcare declining since 2009 (Eurostat, 2014).

On the other hand, they are almost fully satisfied with factors like 'quantity of recreation areas', 'interpersonal relationships', 'air quality' and 'municipality image'. 


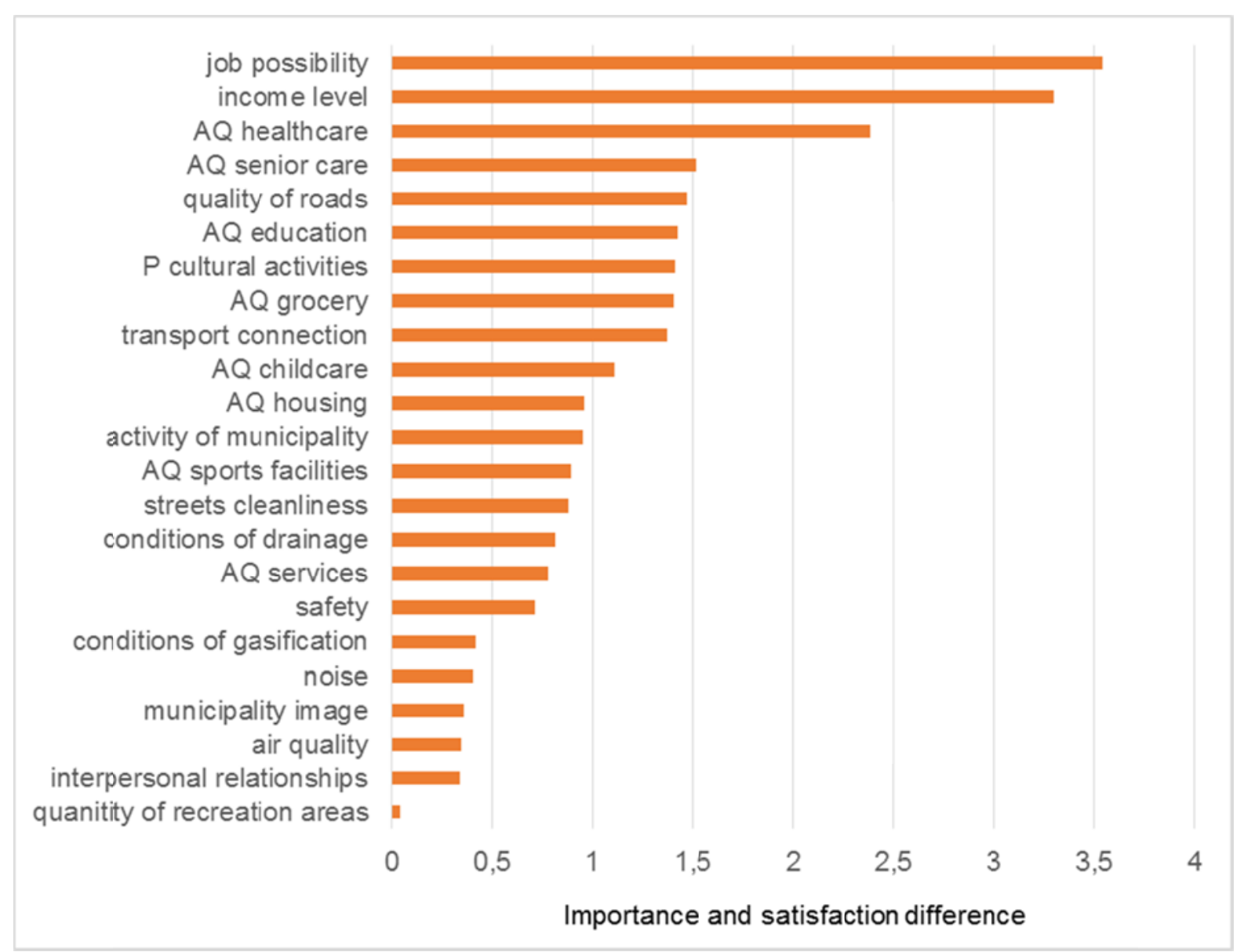

Figure 3. Importance and satisfaction with factors influencing rural standards of living differences order

Although the issue of standards of living in rural regions was examined by many authors (e.g. Wan, 2007; Quiroga, 2007; Hampl, 2007) they weren't focused on the topic of SMEs and their impact on standards of living of its environment. Authors' research try to fill in the gap and in the paper analyzed if characteristics of SME (where the head of household works) has impact on the positive contribution to the development of its environment and also if there exists correlation between characteristics of SMEs and household's satisfaction with standards of living which is assume by authors.

Table 1. SMEs' contribution to the positive development of its environment - according to the number of employees

\begin{tabular}{lccc}
\hline number of employees & & not contribute & contribute \\
\hline up to 9 & absolute & 112 & 9 \\
\hline 10 to 49 & relative & $93 \%$ & $7 \%$ \\
\hline & absolute & 125 & 13 \\
\hline 50 to 249 & relative & $91 \%$ & $9 \%$ \\
\hline & absolute & 118 & 12 \\
\hline
\end{tabular}

Source: Authors' results. 
Table above show if the SME's size has an impact on the (no)contribution to the development of its environment ${ }^{2}$. The results indicate that there are not bigger differences between SMEs devided by their size. Table 1 shows that SME's size hasn't impact on the contribution. Respondents claim that $91 \%$ of small and medium-sized enterprises do not contribute to the development. In the case of micro-sized enterprises is difference just $2 \%$ when $93 \%$ of them do not contribute to the development of its environment. It means that it doesn't matter whether there will be medium-sized or micro-sized enterprises in the rural region.

Table 2. SMEs' contribution to the positive development of its environment - according to the legal form

\begin{tabular}{lccc}
\hline legal form & & not contribute & contribute \\
\hline Self-employed & absolute & 61 & 10 \\
\hline & relative & $86 \%$ & $14 \%$ \\
\hline Private limited company (Ltd.) & absolute & 133 & 4 \\
\hline & relative & $97 \%$ & $3 \%$ \\
\hline Joint stock company & absolute & 74 & 11 \\
\hline & relative & $87 \%$ & $13 \%$ \\
\hline Cooperative (coop) & absolute & 18 & 1 \\
\hline & relative & $95 \%$ & $5 \%$ \\
\hline Special partnership & absolute & 6 & 1 \\
\hline & relative & $86 \%$ & $14 \%$ \\
\hline State enterprise & absolute & 52 & 4 \\
\hline & relative & $93 \%$ & $7 \%$ \\
\hline Civil society organization (CSO) & absolute & 7 & 1 \\
\hline & relative & $88 \%$ & $12 \%$ \\
\hline Other & absolute & 4 & 2 \\
\hline & relative & $67 \%$ & $33 \%$ \\
\hline
\end{tabular}

Source: Authors' results.

Due to insufficient number of respondents in some categories (e.g. special partnership or CSO), authors of the paper consider results showed in the Table 2 as informative. And will be serve as a basis for further research. Results suggest the most contribution in the case of Self-employed SMEs. Interest of Self-employed enterprises about development of its environment explains e.g. Skála (2009) who states that these entrepreneurs try to maximize the development of the environment near the place of residence they come from.

In the case of SME's distance from household's residence are visible small differences. It is obvious, that distance between SME's place of business and household's residence plays role. Findings shown in the table indicate, that the farer household's residence is, the less SME's contribution is perceived (the biggest difference can be seen in the case of 'in next village' and 'in a district' - 11\%). It seems, that although households' respondents work in the enterprise, the farther they live, the less information about its contribution they have.

\footnotetext{
${ }^{2}$ Contribution to the development of SME's environment was based on subjective respondent opinion.
} 
Table 3. SMEs' contribution to the positive development of its environment - according to the distance from households' residence

\begin{tabular}{lccc}
\hline distance from residence & & not contribute & contribute \\
\hline in a village & absolute & 120 & 18 \\
\hline & relative & $87 \%$ & $13 \%$ \\
\hline in next village & absolute & 72 & 10 \\
\hline & relative & $88 \%$ & $12 \%$ \\
\hline in a district & absolute & 101 & 3 \\
\hline & relative & $97 \%$ & $3 \%$ \\
\hline in a county & absolute & 53 & 3 \\
\hline & relative & $95 \%$ & $5 \%$ \\
\hline in next county & absolute & 8 & 0 \\
\hline & relative & $100 \%$ & $0 \%$ \\
\hline
\end{tabular}

Source: Authors' results.

It should be mentioned, that results showed above may not be consistent with real behaviour or SMEs - their contribution to the positive development of its environment because they are based on subjective opinion of SMEs' employees. Based on this, authors are going to continue in the research and confirm or refute these findings.

In order to statistically determine correlation between SME's size, legal form or distance from household's residence and impact on the contribution to the development of SME's environment the hypotheses testing was performed. First the null and alternative hypothesis about (in)dependence between mentioned characteristics were formulated.

\section{1) number of employees}

$\mathrm{H}_{0}$ : Contribution to the development of SME's environment is not dependent on the number of SME's employees.

$\mathrm{H}_{1}$ : Contribution to the development of SME's environment is dependent on on the number of SME's employees.

\section{2) legal form}

$\mathrm{H}_{0}$ : Contribution to the development of SME's environment is not dependent on the legal form of the SME.

$\mathrm{H}_{1}$ : Contribution to the development of SME's environment is dependent on the legal form of the SME.

\section{3) distance from residence}

$\mathrm{H}_{0}$ : Contribution to the development of SME's environment is not dependent on the SME's distance from household's residence.

$\mathrm{H}_{1}$ : Contribution to the development of SME's environment is dependent on the SME's distance from household's residence.

Table 4 shows the results of hypotheses testing based on Pearson's Chi-squared test of independence between observed variables.

Table 4. Hypothesis testing - contribution to the rural development

\begin{tabular}{lccc}
\hline & $\mathrm{p}$-value & Cramer's c.c. & $\mathrm{H}_{0}$ \\
\hline number of employees & .82842 & .0311095 & not rejected \\
\hline legal form & .02831 & .2007065 & rejected \\
\hline distance from residence & .03203 & .1647361 & rejected \\
\hline
\end{tabular}

Source: Authors' results. 
Based on results from Table 4 we can summarize that the first null hypothesis about independence between variables may not be rejected but second and third null hypothesis may be rejected. So the conclusion is that there doesn't exist correlation between SME's contribution to the development of its environment and its number of employees but exists correlation between contribution to the development of SME's environment and SME's legal form and its distance from household's residence. But a Cramer's contingency coefficient say that the correlation is a weak (see Table 4). The result concerning the SME's size wasn't assumed by authors. It was assumed that bigger SMEs with more employees and greater capital are more focused on social responsible activities. In the case of the third hypothesis, authors assume that the result is influenced by the situation that the farther from household's residence SME is, the less information about its activities (and contribution) has. Authors didn't assume dependence.

The next question was, if there exists correlation between characteristics of SMEs and household's satisfaction with standards of living. The hypotheses testing was performed to answer the question.

\section{1) number of employees}

$\mathrm{H}_{0}$ : Household's satisfaction with standards of living is not dependent on the number of SME's employees.

$\mathrm{H}_{1}$ : Household's satisfaction with standards of living is dependent on the number of SME's employees.

\section{2) legal form}

$\mathrm{H}_{0}$ : Household's satisfaction with standards of living is not dependent on the SME's legal form.

$\mathrm{H}_{1}$ : Household's satisfaction with standards of living is dependent on the SME's legal form.

\section{3) distance from residence}

$\mathrm{H}_{0}$ : Household's satisfaction with standards of living is not dependent on the SME's distance from household's residence.

$\mathrm{H}_{1}$ : Household's satisfaction with standards of living is dependent on the SME's distance from household's residence.

Table 5. Hypothesis testing - satisfaction with standards of living

\begin{tabular}{lccc}
\hline & $\mathrm{p}$-value & Cramer's c.c. & $\mathrm{H}_{0}$ \\
\hline number of employees & .55799 & .0792803 & not rejected \\
\hline legal form & .71983 & .1201808 & not rejected \\
\hline distance from residence & .02861 & .1400744 & rejected \\
\hline
\end{tabular}

Source: Authors' results.

Table 5 shows expectable results. First two hypotheses about independence between household's satisfaction with standards of living and SME's number of employees and legal form were not rejected. Just the third hypothesis concerning to the distance from household's residence was rejected so we can claim that there may exists weak dependency between two variables.

Figures 4-6 show detailed look at the correlation between household's satisfaction with standards of living and characteristics of SME where the head of household is employed. 


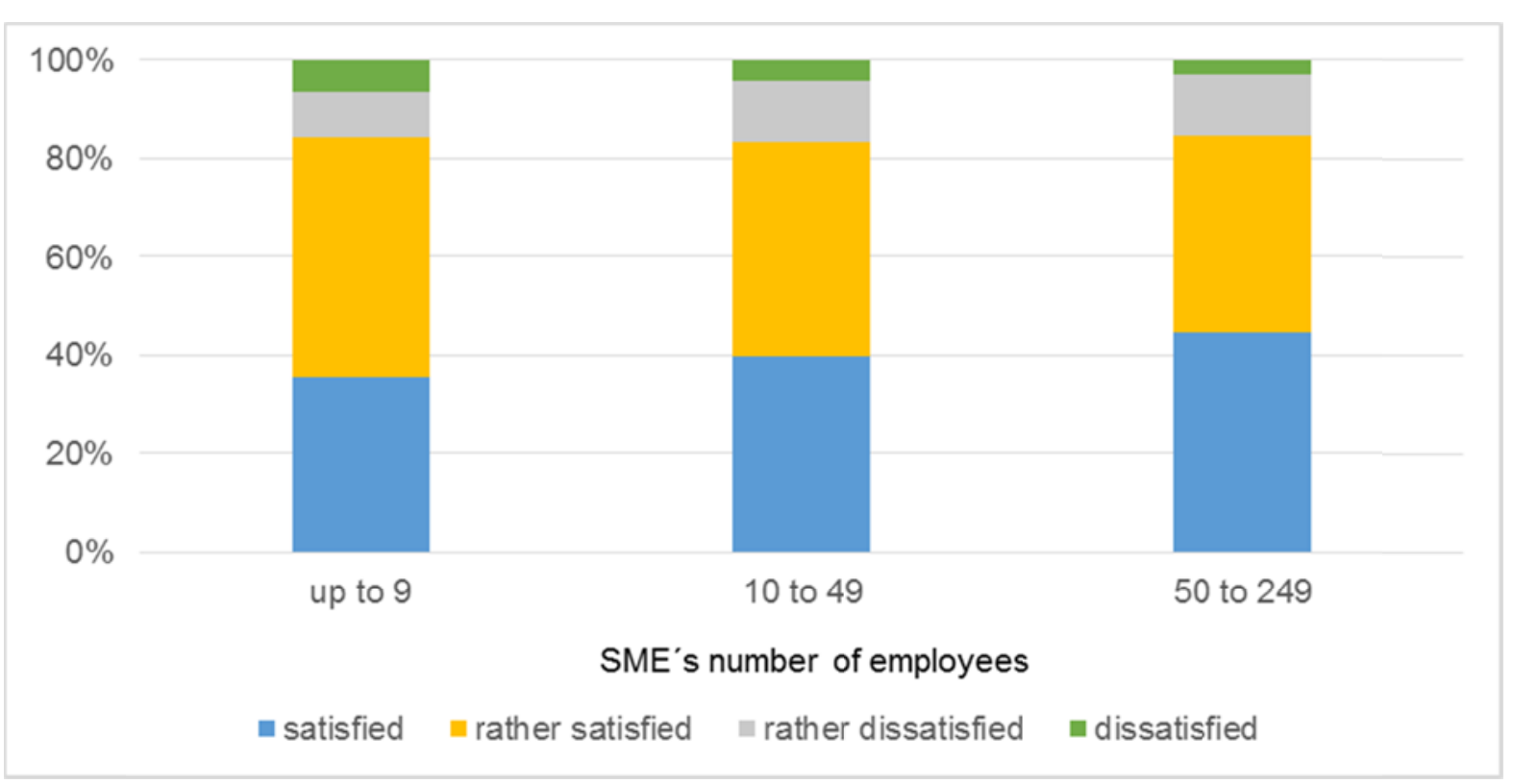

Figure 4. Households' satisfaction with standards of living according to the SME's numbers of employees

The Figure 4 shows that SME's number of employees where the head of households work does not influence households' satisfaction with standards of living. In every column is about $85 \%$ of households satisfied or rather satisfied. The rest of approximately $15 \%$ are dissatisfied or rather dissatisfied. It means, significant differences were not observered.

In the case of SMEs legal form and distance from households' residence (see Figure 5 and 6 ) it is visible that there are bigger differences between household's satisfaction with standards of living. But in the Figure 5 it is caused especially by the small number of respondents of Special partnership, Civil society organization and other business entities.

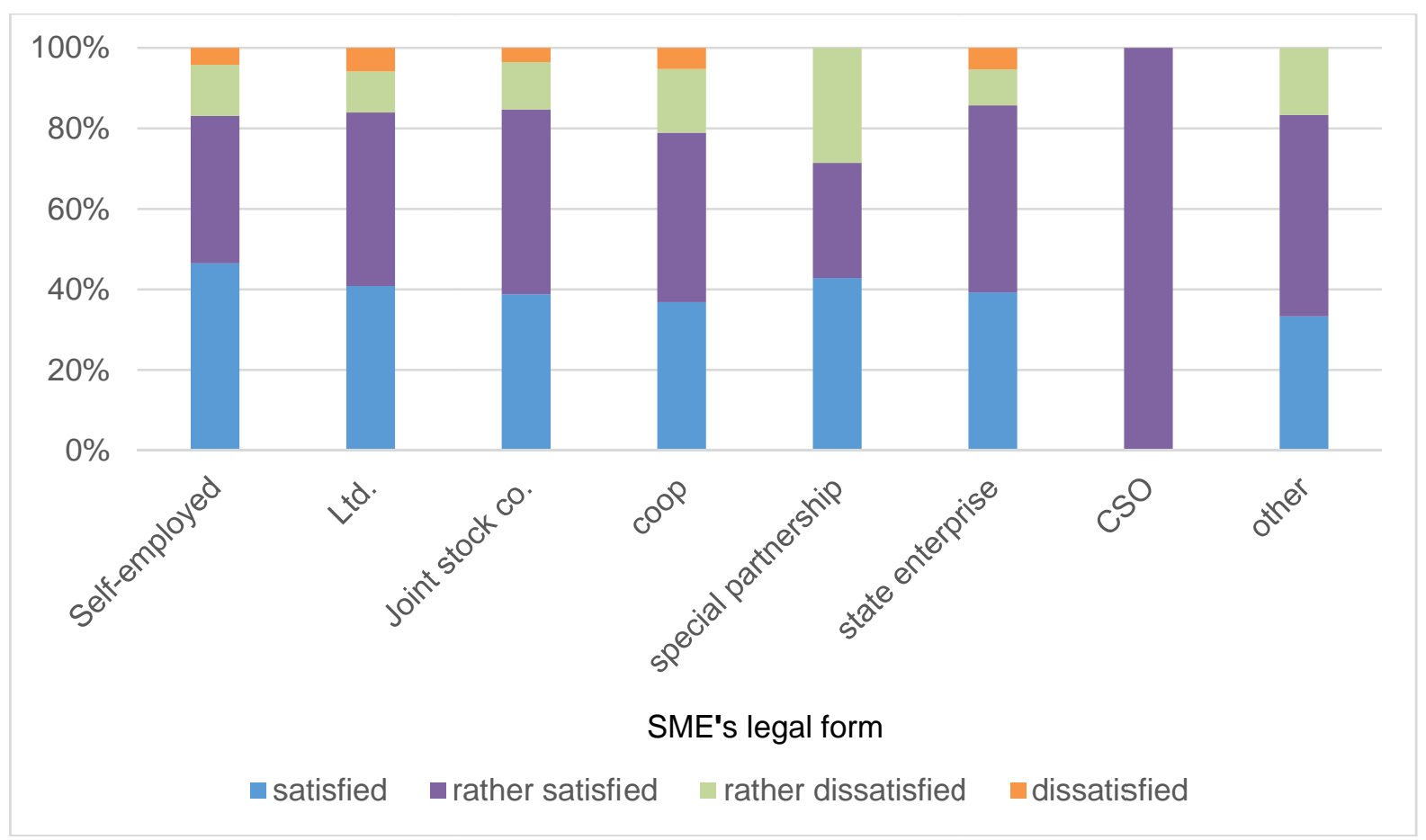

Figure 5. Households' satisfaction with standards of living according to the: SME's legal form 


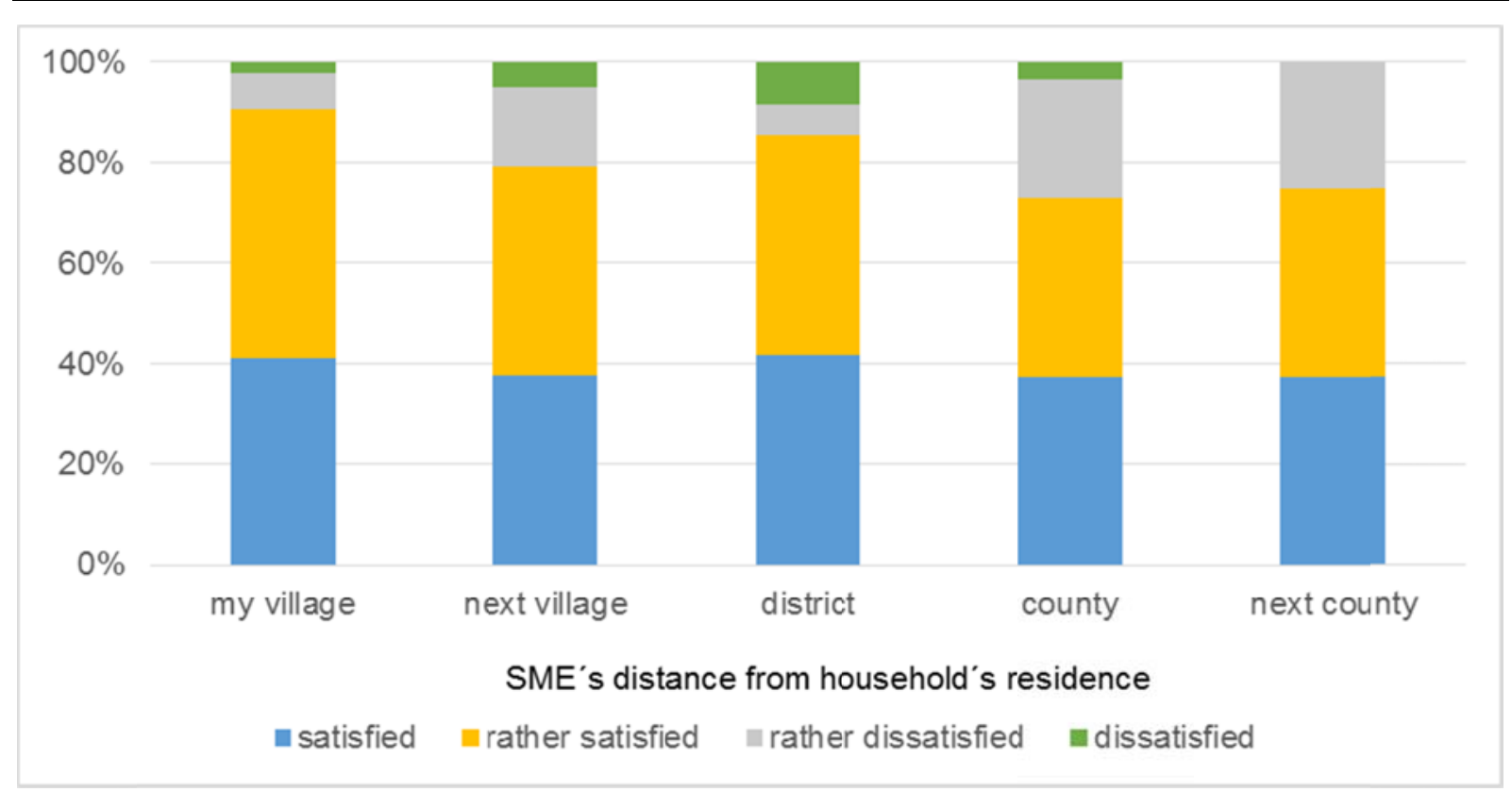

Figure 6. Households' satisfaction with standards of living according to the SME's distance from household's residence

Our findings shown in the Table 5 and the Figure 6 indicates that the farther from household's residence the SME is the less satisfied the household will be with standards of living. This implication was assumed by the authors' in the beginning of the research. One of the reasons we see that SMEs that are located close to the households' residence the mean especially save time and money on commuting. More free time and money can then be used, for example, for building interpersonal relationships and meet material needs, causing a rise in standards of living.

\section{Conclusion and discussion}

The paper determines perceived importance and satisfaction of 389 Czech rural employed households with standards of living and also investigates the relationship between characteristics of SMEs and their impact on households' satisfaction with standards of living and possitive contribution to the development of SME's environment. Based on results presented in the paper, households differently perceive importance and satisfaction with standards of living. It means, there is a difference between expected and actually perceived situation. It was found out that three factors like 'job possibility', 'income level' and 'availability and quality of healthcare'have the biggest difference and should be on a higher level. These factors should rural policy focus on and prepare such conditions which would help to increase their level.

With respect to the characteristics of SMEs and their contribution to the positive development of their environment it was established that there exists weak correlation between the development and legal form of SMEs and the development and SMEs' distance from households' residence.

In the case of households' satisfaction with standards of living there exists weak correlation between the satisfaction and SMEs' distance from households' residence. It seems that the farther from households' residence the SME is the less satisfied the household is with standards of living. 
Based on these findings, we recommend to rural policy to continue supporting of rural SMEs and focus especially on the local Self-employed SMEs or Joint stock companies as the most valuable eterprises.

With respect to results mentioned above, we claim that small and medium enterprises play an important role for analyzed rural households and their standards of living. But we have to note that examined sample of rural employed households is not representative so results results mentioned in the paper can't be generalized. Results are also based on the subjective opinion of heads of households which may be affected by many variables. It is the reason why we would like to compare these results with objective data of statistical offices, ministries, etc. in the next research.

\section{Acknowledgement}

A published article is the result of the project titled: "Standard of living development in Czech rural areas in the context of Small and medium-sized enterprises" funded from sources IGA PEF MENDELU in Brno.

\section{References}

Bourne, L. (2011), Advising Upwards: Managing the Perceptions and Expectations of Senior Management Stakeholders, Management Decision, 49(6), pp. 1001-1023.

Cottam, H. R. and Mangus, A. R. (1942), A Proposed Definition of Standard of Living, Social Forces, [Online], 21(2), pp. 177-179, DOI: 10.2307/2570553, [Accessed 29 February 2015].

European Commision (2014), A harmonised definition of cities and rural areas: the new degree of urbanisation, Regional Working Paper 01/2014, 28 p.

Eurostat (2015), Minimum wage statistics - Statistics Explained, available at: http://ec.europa.eu/eurostat/statistics-explained/index.php/Minimum_wage_statistics [Accessed 26 October 2015].

Eurostat (2015), Urban-rural typology - Statistics Explained, available at: http://ec.europa.eu/eurostat/statistics-explained/index.php/Urban-rural_typology [Accessed 19 February 2015].

Hampl, M. (2007), Regionální diferenciace současného socioekonomického vývoje v České republice, Czech Sociological Review, 43, pp. 889-910.

Holmes, T. J. and Schmitz, J. A. Jr. (1990), A Theory of Entrepreneurship and its Application to the study of Business Transfers, Journal of Political Economy, 98(2), pp. 265-294.

Ministerstvo průmyslu a obchodu (2012), Koncepce podpory malých a středních podnikatelì na obdobi let 2014-2020, 131 p., available at: http://download.mpo.cz/get/47605/54370/599916/priloha002.pdf [Accessed 1 February 2015].

OECD (2006), The new rural paradigm policies and governance, Paris: OECD.

Mainardes, E. W., Alves, H., and Raposo, M. (2011), Stakeholder Theory: Issues to Resolve, Management Decision, 49(2), pp. 226-252.

Milbourne, P. and Doheny, S. (2012), Older people and poverty in rural Britain: Material hardships, cultural denials and social inclusions, Journal of Rural Studies, 28(4), pp. 389-397.

Mottioar, Z. and Ryan, T. (2007), The Role of SMEs in Tourism Development: An Industrial District Approach Applied to Killarney, In: Tourism in the New Europe, 1st Ed. Ireland: Elsevier, Ltd., pp. 63-78. 
OECD (2014), Health at a Glance: Europe 2014, OECD Publishing, available at: http://ec.europa.eu/health/reports/docs/health_glance_2014_en.pdf [Accessed 1 November 2015].

Quiroga, M. (2007), Poor areas or poor people: Decomposing differences in living standards and poverty, Working paper [Online], available at: http://www.ssrn.com/abstract=1150316 [Accessed 20 March 2015].

Ryan, R. M. and Deci, E. L. (2001), On happiness and Human Potentials: A Review of Research on Hedonic and Eudaimonic Well-Being, Annual Review of Psychology, [Online], 52(1), pp. 141-166, DOI: 10.1007/978-94-007-0753-5_3778, [Accessed 29 March 2015].

Sen, A. (1989), The standard of living, 1st Ed. Cambridge: Cambridge University Press.

Shin, D. CH. and Inogichi, T. (2009), Avowed Happiness in Confucian Asia: Ascertaining its Distribution, Patterns, and Sources, Social Indicators Research, 92(2), pp. 405-427.

Skála, V. (2009), Mohou místní akční skupiny v ČR plnit roli strategického partnera menšich obcí pro uplatňováni prvků strategického vládnutí na venkově? Master Thesis, Prague: Univerzita Karlova v Praze. Fakulta sociálních věd.

Stiglitz, J. E., Sen, A., and Fitoussi, J. P. (2007), Commision in the Measurement of Economic Performance ad Social Progress, Issue paper 25/07/08, 37 p.

Terluin, I. J. (2003), Differences in economic development in rural regions of advanced countries: an overview and critical analysis of theories, Journal of Rural Studies, 19(3), pp. 327-344.

Vand'urová, H. and Mühlpachr, P. (2005), Kvalita života: Teoretická a metodologická východiska, Brno: Masarykova univerzita.

Večerník, J. (2012), Subjektivní indikátory blahobytu: př́stupy, měření a data, Politická ekonomie, 60(3), pp. 291-308.

Wan, G. (2007), Understanding Regional Poverty And Inequality Trends In China: Methodological Issues And Empirical Findings, Review of Income and Wealth, 53, pp. 25-34. 